\title{
Türkiye'nin Ulusal Afet ve Acil Durum Yönetim Sisteminin Mevcut Hali ve Yeni Bir Yönetim Modeli Önerisi
}

\author{
Fatih YAMAN ${ }^{1}$, Evren AYRANCl ${ }^{2}$, İsmail Hakkı HELVACOĞLU ${ }^{3}$
}

\section{Öz}

Afet ve Acil Durum Yönetimiyle ilgili ülkemizde ve Dünya'da, özellikle son yirmi yılda çok hızlı değişen yönetim yaklaşımları görülmektedir. Buradaki temel husus, yaşanılan olayların şiddetleri ve sıklıkları olmakla birlikte; farklı çevresel, bölgesel ve küresel gelişmeler de bu değişimleri zorunlu kılmaktadır. Söz konusu gerçeğin bilincinde olarak bu çalışmada; hem Ülkemizin ve hem de farklı ülkelerin kurumsal yönetim yapıları ve operasyonları göz önünde bulundurulmuş ve bu suretle Ülkemiz için daha etkin ve verimli bir Afet ve Acil Durum Yönetim modeli önerilmesi amaçlanmıştır. Çalışmada, öncelikle farklı ülkelerdeki Yönetim Sistemleri incelenmiş ve yönetim yaklaşımları tespit edilmiştir. Bunu takiben, konu açısından Ülkemizdeki tarihsel gelişim süreci ile ilgili yönetim sistemleri özetlenmiştir. Bu sürecin bir devamı olarak Ülkemizdeki ve ele alınan diğer ülkelerdeki Afet ve Acil Durum Yönetim Sistemlerinin farklılıkları ve bu farklılıklara yol açan sebepleri ortaya konmuştur. Konu hakkında yorumlar yapıııken, Ülkemizdeki yeni Başkanlık Sisteminin, Bütünleşik Afet ve Acil Durum Yönetim sistemine ne gibi faydalar sağlayacağı açısından da çeşitli görüşler bildirilmiştir. Tüm bu yapılanların ışığında, çalışmaların ana amacına yönelik olarak yeni ve geliştirilmiş bir Milli Afet ve Acil Durum Yönetim Enstitüsü'nün ne şekilde teşkil edilebileceği ele alınacaktır. Bu bağlamda sadece ilgili birimlerin ve merkezlerin görev tanımları, yetkileri ve birbirleri ile olan bağlantıları gibi idari konularla sınırlı kalınmayacak; aynı zamanda Afet ve Acil Durum çalışanlarının ve gönüllerinin yetkinliklerinin geliştirilmesi, yetkinliklerinin güncel tutulması ve bunların belirli bir standarda oturularak, bunun belgelendirilmesi gibi teknik konular üzerinde de durulacaktır. Bu çalışma konusu aynı zamanda bir doktora tezi şeklinde sürdürülen daha kapsamlı bir çalışmanın bir parçasıdır.

Anahtar Kelimeler: AFAD, Bütünleşik Afet ve Acil Durum Yönetimi, Dayanıklılı, Yeni Başkanlık Sistemi, Türkiye.

\section{Current Situation of Turkey's National Disaster and Emergency Management System and a Suggestion for a New Management Model}

\begin{abstract}
\footnotetext{
${ }^{1}$ Afet Yönetimi Uyg-Ar Merkezi, İstanbul Teknik Üniversitesi

${ }^{2}$ İşletme Bölümü, Beykent Üniversitesi

${ }^{3}$ Gemi ve Deniz Teknolojisi Mühendisliği Bölümü, İstanbul Teknik Üniversitesi

*Ilgili yazar / Corresponding author: fatih.yaman@itu.edu.tr
}

Gönderim Tarihi / Received Date: 12.03.2020

Kabul Tarihi / Accepted Date: 19.11.2020
\end{abstract}

In the last two decades, there have been very rapidly changing Disaster and Emergency Management (DEM) approaches in Turkey and in the world. Environmental, regional and global developments, as well as the severity and frequency of disasters have necessitated this change. The main purpose of this study, being aware of the truth; In the DEM, corporate governance structures and operations of both our country and different countries have been taken into consideration and thus, a more effective and efficient DEM model has been proposed for our country. First, DEM systems in different countries will be examined and their DEM approaches will be reviewed. Then, the historical progress in Turkish DEM systems will be summarized. As a continuation of this process, the differences of DEM Systems in our country and other countries discussed and the reasons that lead to these differences have been 
revealed. While making comments on the subject, various opinions were expressed in terms of the benefits that the new Presidential System in our country would provide to the DEM system. In the light of all these, the main purpose of the studies will be how a new and improved National DEM Institute can be established. In this context, it will not be limited only to administrative issues such as job descriptions, powers and interconnections of the relevant units and centers; technical issues such as improving the competencies of DEM employees and their volunteers, keeping their competencies upto-date, and documenting them to a certain standard.

Keywords: Comprehensive Disaster and Emergency Management, Presidential Management System, Resilience, Turkey.

\section{GiRiş}

Afet ve Acil Durum Yönetimi, Dünya'da ve ülkemizde önemi daha dramatik tecrübelerle öğrenilen, önemi her geçen gün daha da artan, disiplinler arası bir akademik çalışma ve uygulama alanı olarak karşımız çıkmaktadır. Afetleri, genel olarak doğal ve doğal olmayan olarak iki ana kısaca ayırmış olsak da; bilimsel olarak baktığımızda doğal, insan ve teknoloji kaynaklı olmak üzere olmak üzere üç farklı özellik arz ettiği görülmektedir. Her üç tipte de, afetler gerçekleştiğinde insanların ve dolayısıyla toplumun fiziksel, ekonomik ve sosyal yaşantısını kısa veya uzun süreli olmak üzere kesintiye uğrattığı görülmektedir. Afetlerde can ve mal kaybı ile iş sürekliğinin aksaması kaçınılmaz birer durum olarak toplumda derin etkiler oluşturur ve ekonominin ciddi kayıplara uğramasına sebebiyet verebilir. Bu durum, aynı zamanda afetin etki alanının genişlemesi anlamını da taşımaktadır. Afetlerin olumsuz etkilerinin tamamını ortadan kaldırmak mümkün görünmese de; bilgiye dayalı, bütünleşik afet yönetimi stratejileri yardımıyla hazırlanan planlar ve zarar azaltma odaklı çalışmalar, afetlerin negatif sonuçlarını azaltma konusunda yol gösterici olabilir (Seneviratne, 2011). Bu nedenle, yerleşim alanlarında ve sanayi bölgelerinde afetlere karşı mukavemetin arttırıması ve önceden oluşması muhtemel risklerin mümkün olduğunca azaltılması ve/veya ortadan kaldırılması için yapılacak faaliyetler gerekli bir zorunluluktur. Afetlerin, can ve mal kayıplarına yol açarak günlük yaşamın devamlılığını önemli ölçüde etkilediği bir gerçektir ve bugüne kadar birçok acı tecrübe ile kanıtlanmıştır. Birçok ülkede ağır ekonomik ve sosyal kayıplara yol açarak gelişme ve kalkınmayı sekteye uğratmaktadır. Ülkemiz de sıkça çeşitli afetlere maruz kalmakta ve bunlardan ciddi zararlar görebilmektedir. Özellikle deprem, sel, heyelan, çığ, kaya düşmesi, orman yangınları, şiddetli yağış, don, fırtına, kuraklık, ulaştırma kazaları, endüstriyel kazalar, maden kazaları, kritik yapı çökmeleri, çevre kirliliği ve yangınlar ülkemizde en fazla kayıp ve hasara yol açan tehlikelerin yol açtığı afetler olarak dikkat çekmektedir (Şener ve diğ., 2003). Afet yönetiminin başlıca görevi, can ve mal kaybını azaltmak ve ulusu doğal, teknolojik ve insan faktörlü afetlerden korumaktır. Bunu yaparken zarar azaltma, hazırıklı olma, müdahale, ve iyileştirme gibi öğeleri içeren riske dayalı, kapsamlı bir afet ve acil durum yönetim sisteminde tüm paydaşları (kamu, özel sektör, halk) ve tüm kaynakları ile halka öncülük etmeli ve destek verilmelidir (Kadığlu, 2008). Bu konudaki yönetim anlayışının; son on yılda ivil savunma yaklaşımından, Bütünleşik Afet ve Acil Durum Yönetimi Yaklaşımına evrilmekte olduğu görülmektedir. Ülkemizde ve diğer ülkelerde Afet ve Acil Durum Yönetimi organizasyonlarında farklı paradigmalar ve yönetim modelleri bulunmaktadır. Küresel ve bölgesel gelişmeler doğrultusunda bu modellerde çeşitli uyumlaştırıcı, geliştirici ve ya düzenleyici adımlar atılması gerekmektedir.

\section{AFET VE ACIL DURUM YÖNETIMININ TARIHSEL SÜRECI VE PARADIGMALAR}

Her konuda olduğu gibi afet konusunda da insanların karşılaştığı güç durumlar karşısında oluşturdukları mekanizmalar ve bu mekanizmaları zaman içinde geliştirmeleri sonucu, konu bugünkü seviyesine evrilerek ulaşmıştır. Kısa bir zaman dilim içerisinde hızlı ve radikal değişikler sonucu gelişme göstermiş bir konudur. Bu aşamaya gelene kadar farklı tecrübeler 
sonucu farklı anlayışlar ve yaklaşımlar geliştirilmiş, sentezlenerek günümüzdeki yönetim anlayışına gelinmiştir. Afet ve Acil Durum Yönetimindeki ilerleme ve gelişim özellikle son 80 yıl içerisinde dikkat çekici bir hale gelmiştir. Bu süre zarfında Afet ve Acil Durum Yönetimi farklı merhalelerden geçmiş ve kendi paradigmalarını oluşturmuştur. Tarihsel sırayla, birinci Paradigma 1945-1990 lı yıllar arasındadır ve soğuk savaş dönemi etkisiyle oluşan sivil savunma yaklaşımını ifade etmektedir. Toplumu oluşturan büyük insan kitlelerini, özellikle Kimyasal, biyolojik, radyoaktif ve nükleer tehlikelerden korumak amacıyla oluşturulmuş operasyonel yönü kuvvetli olan bir yapıdır. Tipik özelliği, konuyla ilgili uzman ekiplerden oluşan hazır kuvvetler/ birlikler vasıtasıyla organizasyonun yönetilmesi ve yürütülmesidir. Gerçekleştirilen faaliyetlerin temelinde fiziksel güvenliği tesis etmek amacı yatmaktadır. İkinci Paradigmanın ise özellikle soğuk savaş dönemi sonrasında yani 1990dan itibaren ortaya çıktığı ve 2003 yılına kadar devam ettiği görülmektedir. Sivil savunma yaklaşımı etkisinin giderek öneminin azalması ve afet yönetimi anlayışının oluşması sürecinde etkisini sürdürmüş bir paradigmadır. Soğuk savaş döneminin ardından, toplum yapısının değişimi ve şehirleşmenin artması ile birlikte endüstrinin büyümesi ve gelişmesi, fiziksel güvenliğe dayalı bir savunma yönetiminin bu gelişmelere karşılık veremediğinin anlaşılmasına ve bir takım eksikliklerin fark edilmesine sebep olmuştur. Bu eksiklikler, özellikle insan ve teknoloji kaynakları afetlerin ivme kazanması sonucu yeni bir yaklaşım ihtiyacını gün yüzüne çıkarmıştır. Acil durum yönetimi paradigması tam da bu aşamada karşımıza çıkmaktadır. Sivil savunma mantığındaki hazır kuvvet istihdamının maliyetinin yüksekliği ve oluşan afetlerin biçim değiştirmesi bu paradigmanın oluşumunu tetikleyen en önemli iki faktördür.

Üçüncü paradigma, 2003-2010 yılları arasını kapsamaktadır. Ancak bu paradigma yerini hızla tümtehlikelerib, tümkaynakalrın ve tüm evrelerin hepbirlikte aynı önem derecesinde değerlendirildiği Bütünleşik Afet ve Acil Durum Yönetimi paradigmasına bırakmıştır. Aslında bir geçiş paradigması olarak ta niteleyebileceğimiz bir yaklaşımdır. Tüm tehlikeler ve tüm kaynaklar yaklaşımı göz önüne alınmadığı için kısıtlı ve sınırlı kapasite kullanımı problemiyle karşılaşılmıştır (Kadıoğlu, 2008; Özmen ve Özden, 2013). Bunun yanı sıra büyük olayların/afetlerin yönetiminde küçük operasyon yönetim modellerinin çalışmadığı görülmüştür. Özetle, reaktif yaklaşımdan proaktif yaklaşıma geçilmiştir (Kapucu, 2010).

Literatüre göre, Dördüncü ve son Paradigma ise 2010-2020 yılları arasını içermektedir. Son yıllarda ise bu yaklaşımın üzerine toplumun tümünü afetlere dayanıklı ve mukavim kılacak bir paradigma gelişmiştir. Bu da "Dayanıklı Toplum" paradigmasıdır (Varol, 2017). Temel prensip ise; toplumun tüm tehlikelere karşı tüm kaynakları kullanarak, olası afetlerin farkında olma ve gerekli önleyici faaliyetleri gerçekleştirme noktasında proaktif olması düşüncesidir. Başka bir deyişle, bu paradigmanın temelinde "afet farkındalığına ve kolektif bilince sahip toplum" kavramı yer almaktadır.

Bu dört paradigma, birbirlerinden farklı görmekle birlikte bir noktada benzerlik arz etmektedirler. 


\section{Afetlerde Kamu Yönetimi ve Toplum arasındaki Rol Dağılımının Tarihsel Süreci}

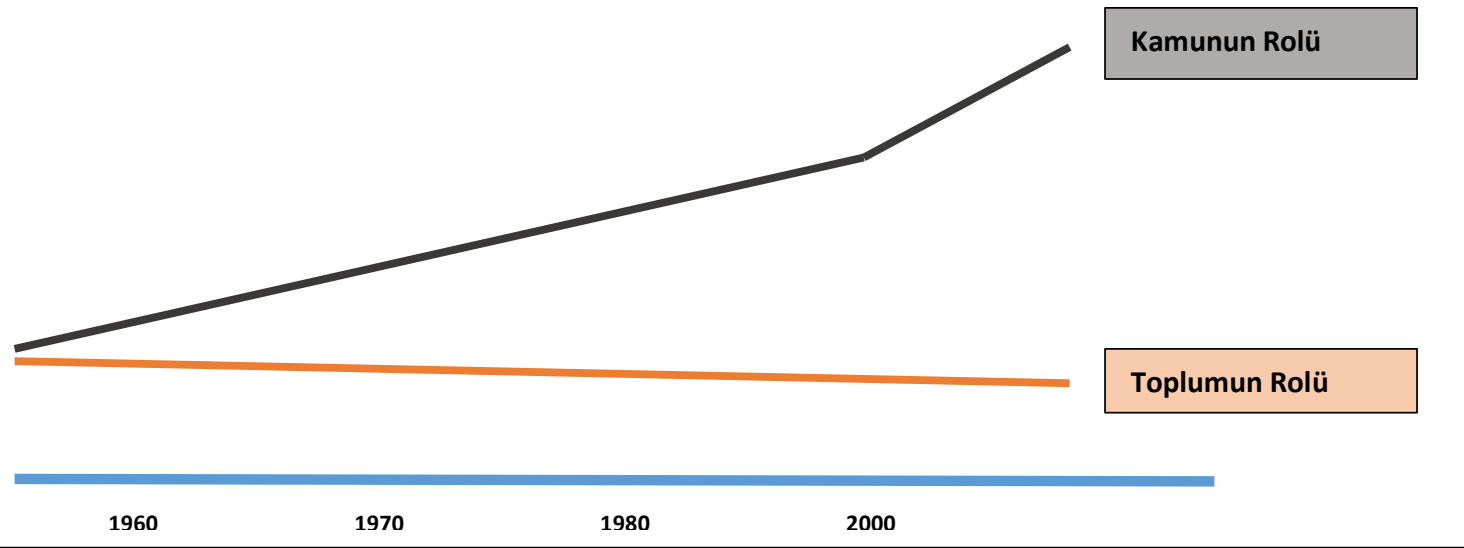

Şekil 1. Afetlerde Kamu Yönetimi ve Toplum arasındaki Rol Dağılımının Tarihsel Süreci (Leblebici, 2014)

Şekil 1'de görüleceği üzere, son altmış yıllık period içerisinde Afet ve Acil Durumlar açısından kamunun rolünün artış gösterdiği ve toplumun rolünün ise nispeten azaldığı ifade edilebilir. Her ne kadar toplumsal dayanışma ve toplum temelli çalışmalar, toplumun mukavemetini ve rolünü arttırsa da kamunun rolü aşağıdaki faktörler sebebiyle hızlı bir ivme ile artış göstermeye devam etmektedir. Buradaki en önemli faktör kamu yönetiminin konuyla ilgili regülasyon değiştirme noktasındaki mutlak gücüdür. Özellikle Risk Yönetimi ve Zarar Azaltma çalışmalarında kamu, elinde bulundurduğu tüm kaynaklar ve kaynakları kullanma aşamasındaki koordinasyon gücü sayesinde konu üzerindeki rolünü arttırmıştır. Modern afet yönetiminin her aşamasında, konununun entegre bir anlayışla yönetilebilmesi için uygulayıcı bir fonksiyondan çok, koordinasyonu sağlayabilecek tüm yetkiyi elinde bulunduran ve tüm kaynaklar ile donatılmış bir kurumsal yapıya intiyaç bulunmaktadır. Bununla beraber yerel seviyede kaynak dağıtımı planlaması da kamunun sorumlu olduğu bir diğer önemli husustur. Bu noktada, afet ve acil durum yönetimi çalışmalarında görev alacak sivil toplum örgütleri ve gönüllü girişimleri açısından da rollerin belirlenip, gerekli insan, ekipman, malzeme ve finans kaynağı faaliyetlerinin koordine edilmesi, kamu yönetiminin en kritik rolleri arasındadır. $\mathrm{Bu}$ konuyu destekleyici bir olay 2004 yılında Birleşik Devletlerde yaşanan kasırga felaketidir. Resmi verilere göre afete müdahale eden kurumların \% 65'i (federal ve yerel) kamu örgütleriyken, özel örgütler \%27, kâr amacı gütmeyen örgütlerin oranı \% 8 olarak tespit edilmiştir (Kapucu, 2008). Buradan görüleceği üzere kamu örgütleri afet ve acil durum koordinasyonunu etkin bir şekilde sağlayarak gönüllü kuruluşların ve diğer sivil toplum örgütlerinin de etkinliğini arttırmıştır (Özerdem ve Jacoby, 2006). Bu noktada; Kamu yönetiminin afet ve acil durum yönetiminde üstlendiği rol ile toplumun rolü arasındaki makasın kamu lehine bu kadar fazla açılmasının ne kadar gerekli olduğu sorulması gereken önemli bir sorudur. Afetlerin sosyal bir olgu olduğunu kabul edersek, toplumun afet konusundaki hassasiyeti ve tepkisi, kamunun afet ve acil durum yönetimindeki sorumluluğu kadar önemli bir olgu olarak karşımıza çıkmaktadır

\section{Afet ve Acil Durum Yönetiminde Global Perspektif ve Türkiye'nin Durumu}

Günümüzde dünya üzerindeki tüm ülkeler afetler ile mücadele etmek durumundadırlar. Bulundukları coğrafya, insan yoğunluğu ve insan faaliyetlerine göre birçok farklı afet türüyle baş etmek durumundadırlar. Yaşanılan tecrübeler ve ülkelerin kültürleri ile orantılı olarak 
afetlerle mücadele konusunda farklı metodolojiler ve yönetim biçimleri oluşmuştur. Afet Yönetim sistemleri temelde afet öncesi, afet esnası ve sonrası olmak üzere ele alınmakla birlikte ülkelerin kendi kamu yapıları, yönetim sistemleri ve karşılaştıkları afet türlerine göre birbirlerinden çok farklı yönetim yapılarının oluşmasına neden olmuştur. Ülkelerin kendi dinamikleri bu yapısal oluşumun ortaya çıkmasındaki en önemli faktördür. Dolayısıyla ülkelerin afet yönetimi yapıları birbirinden çok farklı ve "unique" olarak değerlendirilebilecek bir konumdadır. Afet Yönetiminde uluslararası yardımlaşma organizasyonları olsa da, uluslararası bir afet yönetim modeli söz konusu olamaz. Çünkü afet durumu tüm risklere maruz olabilme, bir zafiyetin (zarargörebilirliğin veya kırılganlığın) oluştuğu ve ülke güvenliği açısından tehditlere daha açık olunan bir durumdur. Özellikle ülke güvenliği boyutundan dolayı afet yönetimi ulusal bir yönetim modeli olarak çalışılmak durumunda olan stratejik bir konudur.

Yönetim ve organizasyon yapıları incelendiğinde; ülkelerin bir kısmı başkanlık seviyesinde, bir kısmı ise bakanlıklar üzerinde doğrudan başbakana ya da başkana bağlı yapılar şeklinde teşkil edilmiştir. Genel olarak "ülke - eyalet/bölge - şehir - olay mahalli" olarak bir hiyerarşik organizasyon silsilesi göze çarpmaktadır. Tüm ülkelerin ortak özelliği ise geçirmiş oldukları her büyük ve yıkıcı afetten sonra afet yönetim modellerini gözden geçirmiş olmaları ve afetten çıkardıkları dersleri yeni yönetim modellerine uygulamaya çalışmalarıdır.

Yönetim sistemlerindeki ortak husus, ülkelerin afet ve acil durum yönetimi yapılarının, merkezi yönetimden yerel yönetime kadar inen bir hiyerarşik düzende kurgulanmış olduğudur. Bu sistem içerisindeki yetki ve sorumluluklar ile görevler arası ilişkiler afet ve acil durum yönetim planlarında yer almaktadır. Özel uzmanlık gerektiren müdahale operasyonları (kimyasal, nükleer, biyolojik sızıntı vs.) dışında ilk müdahale, yerel arama kurtarma birlikleri tarafından yapılmaktadır. Afetin etki alanı büyüdükçe organizasyon yapısı da büyümekte ve komuta kontrol yetkisi hükümet düzeyine kadar ulaşabilmektedir. İrdelenen tüm ülkelerin ortak özelliği, afet öncesi ve afet sonrası işleyişi ve sürekliliği sağlamak üzere kurulmuş bununla birlikte tam zamanlı görev yapan bir koordinasyon kurumunun bulunmasıdır. Bu kurumların bir kısmı bakanlık düzeyinde, bir kısmı ise bakanlıklar üzerinde doğrudan başbakana ya da başkana bağlı yapılar şeklinde teşkil edilmiştir (Şener ve diğ, 2003). Bu çalışmada ülkeler rastgele değil, bir mantık çerçevesinde ve bir hiyerarşi içerisinde belirlenmiştir. Amerika Birleşik Devletleri ve Japonya gibi öne gelen ve aynı zamanda ekol olarak karşımıza çıkan ülkeler ile birlikte, hem komşumuz hem de farklı bir anlayışı temsil e (den büyük coğrafya ya ve stratejik öneme sahip Rusya Federasyonu, Avrupa birliğinin lokomotif ülkelerinden biri olan ve Avrupa Birliğinin karakteristik özelliklerini temsil eden Fransa bu çalışma için özellikle belirlenmiştir.

\subsection{Amerika Birleşik Devletleri}

Amerika Birleşik Devletleri'nde acil durum yönetimine liderlik etmek Federal Acil Durum Başkanlığı'nın (Federal Emergency Management Agency-FEMA) sorumluluğundadır (Şener ve diğ., 2003). ABD'de afete müdahale mülki idare bölümlerine uygun olarak en küçük yerleşim biriminden başlamakta ve FEMA ile Devlet Başkanına kadar uzanabilmektedir. FEMA'nın yaklaşık 4.000 - 5.000 arasında daimi çalışanı ve ayrıca yarı zamanlı çalışanları bulunmaktadır. FEMA'nın merkezi Washington D.C.'de bulunmaktadır ve bu ofis hem bürokratlardan hem de profesyonel çalışanlardan oluşmaktadır. Bölgesel ofisler, eyalet ve yerel yönetimlerle daha yakın bağlara sahip olmak için ABD genelinde ofisleri bulunmaktadır. Her eyalette ayrıca bir afet ve acil durum yönetim ofisi bulunur. Genellikle, bu bölümler valinin veya kamu güvenliği bölümünün içinde bulunur. Ayrıca, tek başlarına ajanslar olabilir veya eyalet ülke güvenlik birimlerine entegre edilebilirler. Bu acil durum yönetim ofisleri, devletteki acil durum yönetimini teşvik etmek için çalışır. Federal politikanın izlenmesini sağlamaya yardımcı olurlar ve FEMA tarafından sağlanan fonları dağıtırlar (Rubin, 2007). 
FEMA ayrıca afet ve acil durum yönetimi personelini eğitmeye yardımcı olur, eyalet ve yerel düzeyde Zarar Azaltma Eylem Planlarını onaylar ve kurtarma operasyonlarıyla ilgili yardımların dağıtımını denetler (ITÜ, 2005). FEMA daha önceden doğrudan Başkan bağlı olarak faaliyet gösteren bir kurum iken 2003 yılında İç Güvenlik Bakanlığının (Department of Homeland Security) bir alt birimi olarak görev yapmaya başlamıştır. 2001 yılı öncesinde FEMA doğal tehlikelerin neden olduğu afet odaklı bir yaklaşımla hareket ederek faaliyetlerini sürdürmekteydi. Aynı zamanda Kongrenin fonladığı bir kamu kurumuydu. Birleşik Devletler, 2001 yılında gerçekleşen 9/11 Eylül terör saldırılarında terörizm ile yüzleştikten sonra, ülke güvenliği ve istihbarat konuları FEMA'nın da ilgi alanı içerisine dâhil olmuştur. (Federal Office of Civil Protection and Disaster Assistance, 2018). DHS'nin altında bir fonksiyon olarak yer alması da bu gelişmeler neticesi oluşan bir stratejik karardır. FEMA'nın bağımsız bir yapıda olması tartışıısa da Katrina kasırgasındaki başarısızıı bile şu anki organizasyon yapısını etkilememiştir. Katrina kasırgasındaki temel eksikliklerden birinin hazırlık evresi için yeterli fonun ayrılmaması olduğu yönündeki raporlar sonucu, 2007 yılında "Milli Hazırlık Merkezi"'nin yönetimi de FEMA'nın görev alanına dâhil edilmiştir. Tüm bunlara ilaveten, sıradan vatandaşlar, afet ve acil durum yönetimi ile ilgili sayısız önemli görevi yerine getirmektedir. Amerikan vatandaşları, afetler meydana geldiğinde ortaya çıkan faaliyetlerle yoğun bir şekilde ilgilenmektedir. Topluluk Acil Müdahale Ekiplerinin üyeleri olarak giderek daha fazla eğitilmektedirler. Bu nedenle Amerikan afet ve acil durum yönetimi sistemi, neredeyse tüm devlet kurumlarının yanı sıra özel ve kar amacı gütmeyen sektörlerdeki kuruluşlar ve bireylere dayanmaktadır. Aşağıda Şekil 2'de de görüleceği üzere Birleşik Devletlerin 2003 yılı sonrası afet ve acil yönetimiyle ilgili kamu yönetiminin ülke düzeyindeki organizasyon yapısı yer almaktadır.

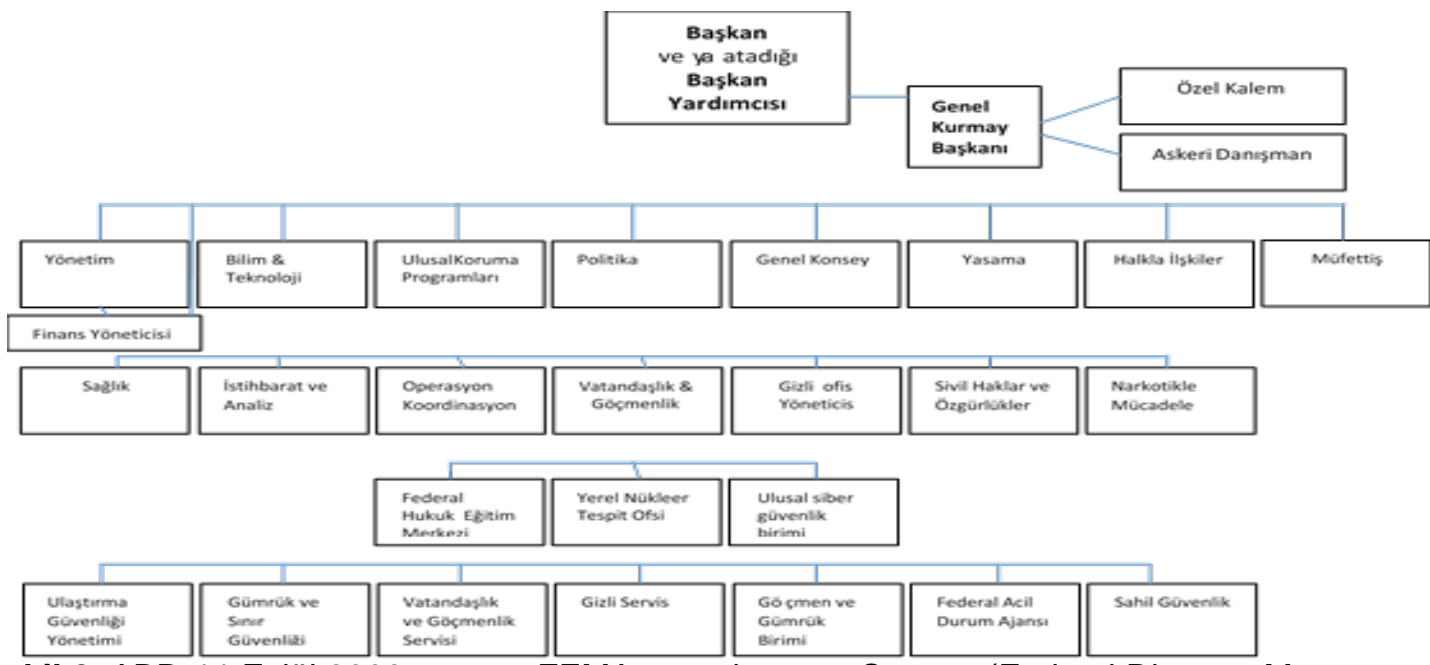

Sekil 2. ABD-11 Eylül 2003 sonrası FEMA organizasyon Şeması (Federal Disaster Management Agency, 2014).

\subsection{Japonya}

Japonya afetlerde her yıl verdiği kayıplar bakımından dünyanın önde gelen ülkeleri arasındadır. Afetlerde verdiği kayıplar bakımından birinci sırada doğal afetler yer almaktadır. Afetlerle ilgili Japonya'nın ulusal önceliği; vatandaşların hayatlarını, geçim kaynaklarını ve mülklerini doğal afetlerden korumaktır. Japonya'da afet ve acil durum yönetim sistemi, büyük ölçekli doğal afetlerin yaşanması sonucu geliştirildi ve güçlendirildi. Japonya, modern ve bütünleşik afet yönetimi yaklaşımının dört aşamasını da etkili ve verimli bir şekilde kullanan, bu konuda engin bir deneyime sahip bir ülkedir (Government of Japan, 2007). Japonya ulusal acil durum yönetim yapısında eşgüdüm fonksiyonu, bütünü ile Ulusal Ülke Ajansı (National Land Agency, NLA) kontrolündedir. Aynı zamanda, kendi fonksiyonu olmayan ve kabinede başka bakanlıklara bağlı olarak faaliyet gösteren örneğin; Deniz Güvenlik Ajansı, 
Meteoroloji Ajansı gibi Ulaştırma Bakanlığına bağlı birimlerin ilişkilerini de sağlamaktan sorumludur. NLA dışında gönüllülük esasına dayalı bir yapılanma da görülmektedir. Gönüllülük geleneği, özellikle tıp alanı ve itfaiye organizasyonunda çok yaygındır. Dünya'da en fazla organize olmuş toplumların başında sayılabilecek ve davranış kalıbı olarak örgütlülüğün küçük yaşlardan beri benimsetildiği Japon eğitim ve toplum yapısı afete dirençli I mukavim toplumun temel taşını oluşturmaktadır. Diğer yandan Japon Uluslararası İşbirliği Ajansı (JICA) özellikle yerel yönetim ve üniversitelerle okyanus aşırı ilişkilerinde afet önleme ve afete karşı önlemler başlığında projelere mali, ayni ve personel-proje desteği vererek o bölgelerden sürekli veri toplamakta ve deneyim birikimine yeni değerler katmaktadır. Ulusal acil durum yönetimi modelinin biçimlenişi için temel dört sorumluluk düzeyi saptanmıştır. Bunlar; Ulusal Hükümet Düzeyi, Bölgesel Hükümet Düzeyi, Belediyeler Düzeyi ve Halk Bireysel Düzeydir. Bunun yanı sıra, afet ve acil durum yönetimi yapısı incelendiğinde, operasyonel kurumlar olarak itfaiye teşkilatının İçişleri Bakanlığına, buna karşın Ulusal Polis Teşkilatının ise Ulusal Halk Güvenlik Komisyonu ajansı çatısı altında doğrudan Başbakana bağlı faaliyet göstermesi dikkate değer bir özellik olarak ortaya çıkmaktadır (Liyanaarachchige, 2016). JDR (Japan Disaster Relief) örgütü ise nakdi yardım yapmaksızın gönüllü seçilmiş personel desteği ile denizaşırı destek faaliyetlerini kendine ait yurt dışı depolarından aldığı ilaç araç gereç desteği ile uzmanlık gerektiren afet destek hizmetlerini üretmekte tüm dünyada operasyonlara katılmaktadır (Şener ve diğ., 2003). Japonya'da her yıl düzenli olarak, toplumun tüm katmanlarının yer aldığı ülke boyutunda bir saha tatbikatı yapılmaktadır. Bu tatbikatta her aile olası bir afet durumunda geçici olarak barınacağı okul, spor salonu gibi toplanma alanlarında bir gece geçirerek hem nasıl bir ortamda nelere intiyacı olacağını hem de yakınında kimlerin bulunacağını tecrübe etmiş olur. Böyle bir tatbikatı gerçekleştirmek gerçekten tüm toplum katmanlarının belirli bir bilinç ve eğitim seviyesinde olmalarını gerektiren bir çalışmadır. Japonya'nın yönetim organizasyonu aşağıda Şekil 3'te görüldüğü gibi diğer ülkelerin organizasyon yapılarına nazaran daha yatay bir organizasyon şemasıdır. Bu, "yetkinin optimum olarak dağıtımı (Span of Control)" açısından da büyük kolaylık sağlayan bir organizasyon yapısıdır.

\begin{tabular}{|c|c|c|}
\hline \multicolumn{3}{|c|}{ JAPONYA AFET YÖNETIMI ORGANIZASYONU } \\
\hline \multicolumn{3}{|c|}{ Basbakan / Afet Yönetiminden Sorumlu Devlet Bakanı } \\
\hline Sorgu & Rapor & Fikir Önerisi \\
\hline \multicolumn{3}{|c|}{ Merkezi Afet Yönetimi Konsevi } \\
\hline \multicolumn{3}{|l|}{ Başkan : Başbakan } \\
\hline \multicolumn{3}{|c|}{$\begin{array}{l}\text { Üyeler : Afet Yönetiminden Sorumlu Devlet Bakanı, Kabinedeki tüm bakanlar, Kabine Sekreteri, Yönetim ve Eşgüdüm Ajansı Hokkaido } \\
\text { Geliştirme Ajansı, Savunma Ajansı, Ekonomik Planlama Ajansı, Bilim ve Teknoloji Ajansı, Çevre Ajansı, Okinawa Geliştirme Ajansı, Ulusal Ülke Ajansı } \\
\text { (National Land Agency) Japon Bankası Başkanı, Japon Kızılhaçı Başkanı, Japon Radyo Televizyon Ajansı Başkanı, Nippon Telgraf ve telefon Başkanı ve } \\
\text { konularında uzman dört akademik üye }\end{array}$} \\
\hline 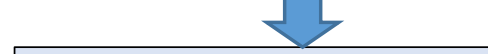 & \multicolumn{2}{|c|}{5} \\
\hline Teknik Araştırma Komiteleri & \multicolumn{2}{|l|}{$\begin{array}{l}\text { Sekreterya Başkanı } \\
\text { Kabinedeki Parlemento Sekreteri } \\
\text { Dansısman } \\
\text { Kabine Sekreteri yardımcııı } \\
\text { Başkan Yardımclsı } \\
\text { Afet Yönetimi Genel Direktörü } \\
\text { Kabinedeki Afet Yönetimi ve Yangın }\end{array}$} \\
\hline
\end{tabular}

Şekil 3. Japonya Afet ve Acil Durum Yönetimi Organizasyon Şeması (Government of Japan, 2007).

\subsection{Rusya}

Eski Sovyetler Birliği yönetim sisteminde, soğuk savaş döneminde pek çok batılı ülkede olduğu gibi afetlerle ilgili yaklaşım ve teşkilatlanma ulusal sivil savunma stratejisi ve örgütü içerisinde düşünülmüştür. Chernobil faciası ve sonrasında faciada yaşanan olaylar eski 
Sovyetler Birliğindeki afet ve acil durum yönetimi anlayışında değişime gitmek zorunluluğunu getirmiştir. Daha sonra ise Rusya Federasyonu olarak yeniden yapılanma sürecinden sonra, Afet ve Acil Durum yönetimi ile ilgili "Sivil Savunma, Acil Durumlar ve Doğal Afet Zararlarının Ortadan Kaldırılması Bakanlığı” olarak ifade edebileceğimiz EMERCOM'u 10 Ocak 1994'te kurmuştur.

EMERCOM Rusya Federasyonunun federal bir yürütme organıdır. Kriz Yönetim Merkezi ise (Crisis Management Center-CMC) ise; günlük olayları takip etmek amacıyla EMERCOM altında faaliyet gösteren bir teşkilattır. Afet ve Acil durum yönetimi ile görevli organizasyonların sürekli kontrolü ve EMERCOM için gerekli bilgilerin sağlanması gibi temel görevleri bulunmaktadır (EMERCOM, 2012). Bunlara ilave olarak, Rusya Afet ve Acil durum Yönetimi konusunda UNHCR, ICDO, UNDHA gibi uluslararası organizasyonlarla yakın işbirliğ ini de sürdürmektedir. Bu işbirlikleri vasıtasıyla, uzun vadeli programların ve projelerin uygulanmasında yer almaktadır. Bakanlık seviyesinde organizasyonel bir yapılanmanın olduğu Rusya Federasyonunda yönetimle ilgili hiyerarşik yapı aşağıda Şekil 4'te görüldüğü üzere kurgulanmıştır. Üst kademe, ana bölümler ve destek bölümleri olarak üç ana kademede teşkil edilmiş bir yapıdır. Bu yapı hem stratejik yönetim, hem de taktiksel ve operasyonel yönetimin tek bir organizasyon şemasında görülebileceği bir durumu içermektedir.

\begin{tabular}{|c|c|c|c|c|}
\hline & & $\begin{array}{c}\text { Ulusal Kriz Yönetim } \\
\text { Merkezi Başkanı }\end{array}$ & & \\
\hline \multicolumn{5}{|c|}{ Üst Kademe Yönetim } \\
\hline $\begin{array}{l}\text { Ulusal Kriz Yönetim } \\
\text { Merkezi Başkan } \\
\text { Yardımcısı }\end{array}$ & $\begin{array}{l}\text { Ulusal Kriz Yönetim } \\
\text { Merkezi Başkan } \\
\text { Yardımcısı }\end{array}$ & $\begin{array}{l}\text { Ulusal Kriz Yönetim } \\
\text { Merkezi } \\
\text { BaşkanYardımcısı } \\
\text { Müdahale }\end{array}$ & $\begin{array}{l}\text { Ulusal Kriz Yönetim } \\
\text { Merkezi Başkan } \\
\text { Yardımcısı Bilgi ve } \\
\text { Destek }\end{array}$ & Mühendislik Başkanı \\
\hline \multicolumn{5}{|c|}{ Ana Bölümler } \\
\hline Müdahale Merkezi & $\begin{array}{l}\text { Bilgi ve Destek } \\
\text { Merkezi }\end{array}$ & Uydu Takip Merkezi & Erken Uyarı Merkezi & $\begin{array}{l}\text { Hava Kurtarma } \\
\text { Merkezi }\end{array}$ \\
\hline \multicolumn{5}{|c|}{ Destek Bölümleri } \\
\hline $\begin{array}{l}\text { Bilgi İletişim } \\
\text { Departmanı }\end{array}$ & $\begin{array}{l}\text { Günlük Yönetim } \\
\text { Departmanı }\end{array}$ & $\begin{array}{l}\text { Gizli Servis } \\
\text { Departmanı }\end{array}$ & $\begin{array}{l}\text { İletişim Kontrol } \\
\text { Deparmanı }\end{array}$ & Personel Departmanı \\
\hline \multirow[t]{3}{*}{$\begin{array}{l}\text { Eğitim ve Psikolojik } \\
\text { Destek Departmanı }\end{array}$} & $\begin{array}{l}\text { Finans ve Ekonomi } \\
\text { Departmanı }\end{array}$ & $\begin{array}{l}\text { Lojistik Destek } \\
\text { Departmanı }\end{array}$ & Ekipman Departmanı & $\begin{array}{l}\text { Mühendislik } \\
\text { Departmanı }\end{array}$ \\
\hline & $\begin{array}{l}\text { Yangın Güvenliği } \\
\text { Departmanı }\end{array}$ & $\begin{array}{c}\text { Planlama ve } \\
\text { Organizasyon Dept. }\end{array}$ & $\begin{array}{l}\text { Bilgi İletişimi } \\
\text { Departmanı }\end{array}$ & \\
\hline & Metodoloji Departmanı & Uzman & $\begin{array}{l}\text { Veteran Destek } \\
\text { Departmanı }\end{array}$ & \\
\hline
\end{tabular}

Şekil 4. Rusya Afet ve Acil Durum Yönetimi Organizasyon Şeması (EMERCOM, 2012) Şekildeki departmanlar ifadesini kaldıralım

\subsection{Fransa}

Günümüzde Fransa afet ve acil durum yönetimi sistemi, acil durum yönetimi etkinliğinin halk tarafından sosyal, ekonomik ve çevresel risk kabul edilerek, toplumsal olarak değerlendirilmesine intiyaç duyulan bir konu olarak görülmektedir. 
Fransa yıllar içinde kazandığı deneyimler sonucunda afet ve acil durum yönetiminde üç ana madde üzerinde ulusal politikalarına yön vermektedir.

a-Doğal, insan kaynaklı ve teknolojik olarak ayırmadan tüm karmaşık riskler üzerinde çalışmak gereklidir.

b-standart prosedürler ve planlar yerel koşullara ve özel durumlara uyarlanmalı ve farklılaştırılmalıdır.

c- afet ve sonrası kurtarma faaliyetleri detayları ile birlikte açıkça tanımlanmalı ve tam olarak işler hale getirilmelidir (Emergency Management Institute, 2014).

Fransa'daki afet ve acil durum yönetim sistemi, sistematik risk değerlendirmesi ve risk yönetimi politikalarına dayanmaktadır. Bu politikalar çoğunlukla Avrupa Birliği (AB) arazi kullanımı, çevresel ve endüstriyel güvenlik direktifleri yoluyla gelişen bir yapıdır. Fransa, risk yönetimi politikalarını aktif olarak oluşturan ve uygulayan lider bir $A B$ ülkesi olarak hareket etmektedir. Fransa Birleşmiş Milletlerin Risk Azaltma inisiyatifinde de yer almaktadır. Fransa ve Avrupa'daki DRR faaliyetlerini teşvik etme konusunda başlangıcından beri aktif olarak faaliyet göstermektedir. Fransa Birleşmiş Milletlerin Risk Azaltma inisiyatifi kapsamında Avrupa Birliği Risk Azaltma adı altında yürütülen stratejik faaliyetlerde yer almaktadır (UNDRR, 2019).

Fransa, 22 büyük bölge ve 4 denizaşırı bölgeye ayrılmıştır. Kamu güvenliği, yerel makamlar ve devlet arasında paylaşılan bir yetkinliktir. Ulusal seviyede, Afet ve Acil Durum Yönetimi faaliyetlerinin koordinasyonu içişleri bakanlığının sorumluluğunda olan bir konudur. Devlet, bölge toplulukları ve kamu kurumları altındaki acil durum kaynaklarını / operasyonlarını koordine eder. Bölge düzeyinde ise, bölge valisi yetki alanındaki acil durum kaynaklarını/operasyonlarını koordine eder.

Ülkede ve yurtdışında oluşabilecek ulusal düzeyde büyük çaplı acil durum operasyonlarında ise, Ulusal Operasyon Merkezi (CODIG) 24 saat boyunca izleme faaliyetini yürütmektedir. Bu merkez, afet ve acil durumlar konusunda İçişleri Bakanını ve Devlet makamlarını bilgilendirmekten sorumludur. Yerel seviyede ki olaylarda ise; her belediyedeki belediye başkanı ve sorumlu vali, risklerin önlenmesinden ve yardım ve kurtarma operasyonlarından sorumludur (European Commision, 2019).

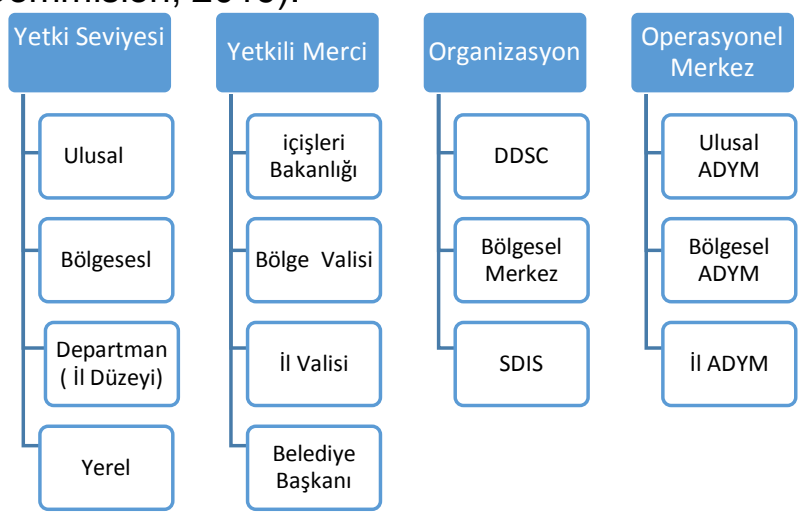

Şekil 5. Fransa Afet ve Acil Durum Yönetimi Organizasyon Şeması (UNDRR, 2019)

Yukarıda Şekil 5'te ifade edildiği gibi; yapı, yetki seviyesi düzeylerinde tanımlanmış olarak görülmektedir. Aynı zamanda her yetki seviyesinde bulunan sorumlu kurumlar da bu yapıda ayrıntılı bir şekilde gösterilmiştir. 


\subsection{Türkiye}

Birleşmiş Milletler ve Avrupa Birliğinin ortak çalışmasıyla hazırlanan küresel boyuttaki afetlerin risk derecelerine göre sınıflandırıldığı 2019 yılı INFORM (Index for Risk Managament/INFORM) raporunda Türkiye'nin 4,9 INFORM endeks puanına (orta derece risk seviyesinde) sahip olduğu görülmektedir (INFORM, 2019). Ülkemizde yapılan afet çalışmaları yakından incelendiğinde maalesef son yıllara kadar, gayretlerin çoğunun afetlerden sonraki "müdahale etme" aşamasına yöneltilmiş olduğu görülür. Ancak, "Afet Yönetimi" sadece insanları enkaz altından kurtarmak, hastaneye yetiştirmek, yangın söndürmek vb. müdahale çalışmalarını yapmak değildir (Kadıoğlu 2008; Özmen ve Özden 2013; Okay 2018, 2019). Aksine "Bütünleşik Afet Yönetimi"nin önceliği (müdahale çalışmalarına duyulabilecek intiyacı da en aza edebilmek amacıyla) insanları tehlikelerden korumak ve mevcut riskleri, afetler olmadan önce azaltmak olmalıdır. 2009 yılında kurulmuş olan Afet ve Acil Durum Yönetim Başkanlığı ülkemiz için bir mihenk taşı olmuştur. Afet yönetimindeki dört aşama yaklaşımı olan hazırlık, Zarar Azaltma, Müdahale ve İyileştirme adımları yapılan bu çalışmada temel alınmıştır. Tüm tehlikeler ve tüm kaynaklar göz önüne alınarak yeni bir yasal mevzuat ve işleyiş oluşturulmaya gayret edilmiştir. AFAD öncesi ve sonrası durumu aşağıda Şekil 6'da gösterildiği gibi belirtmek faydalı olacaktır.

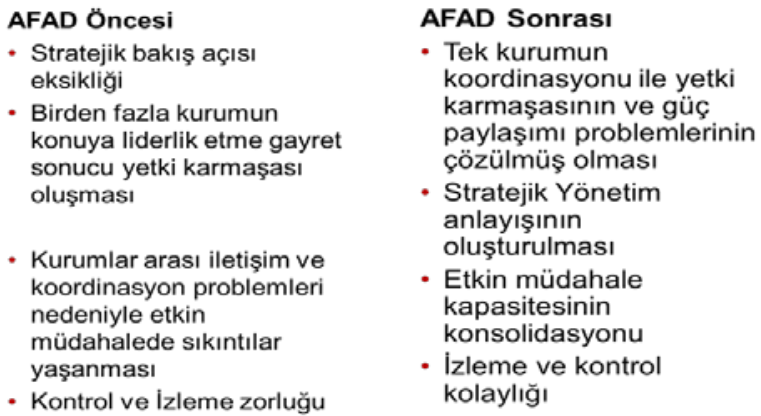

Şekil 6. AFAD yapılanmasının avantajları (Yaman ve diğ., 2019). 


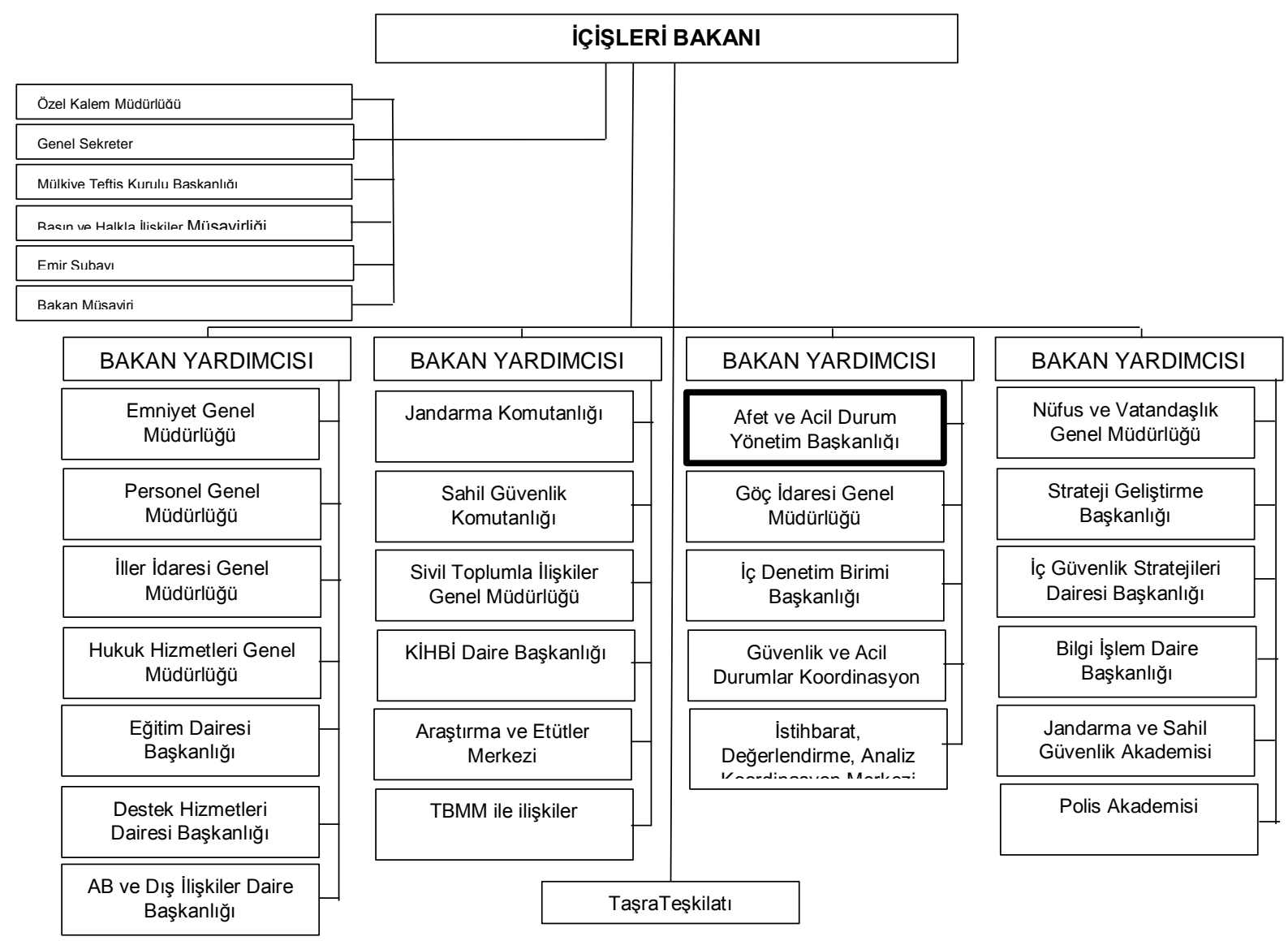

Şekil 7. Türkiye AFAD Organizasyonu (TC İçişleri Bakanlığı, 2019)

Şu anda, Merkezi yönetim sistemimiz; Cumhurbaşkanlığı, Bakanlıklar, yardımcı ve bağlı kuruluşlardan oluşmaktadır. Yerel yönetimler ise köy yönetimleri (muhtarlıklar), belediyeler ve il özel idarelerinden oluşmaktadır. Kurumsal yapıları ve görevleri bakımından merkezi yönetim ve yerel yönetimler, birbirini tamamlayıcı niteliktedirler (Tercan, 2018). Merkezi Kamu yönetiminin taşra yönetimdeki temsilcisi ise Valiliklerdir. İllerde bulunan valilik makamları “ II Afet ve Acil Durum Yönetimi Müdürlükleri” vasıtasıyla konuyla ilgili faaliyetleri yürütür. Kamu yönetimi fonksiyonları bu kurum tarafından organize edilir ve izlenir. Parlamenter sistemde Başbakanlık makamına bağlı olarak faaliyet göstermekte olan AFAD Başkanlığı, yeni geçiş yaptığımız Başkanlık sisteminde İçişleri Bakanlığına bağlı bir kurum olarak 15/7/2018 tarih 30479 sayılı resmi gazetede yayımlanan 4 sayılı Cumhurbaşkanlığı kararnamesi ile çalışmalarını sürdürmektedir Ref. Şekil 7' de görülen İçişleri Bakanlığı organizasyon şemasında, Afet ve Acil Durum Yönetimi Başkanlığının hiyerarşik yapıdaki yeri görülmektedir. Bunula birlikte AFAD'ın merkez ve taşra teşkilatlarında görev ve sorumluluklar da aynı şekilde devam etmektedir.

\section{6 Ülkelerin Afet Yönetim Sistemlerinin Karşılaştırılması Değerlendirilmesi}

Yukarıda irdelenen ülkeler göz önüne alındığında; fonksiyon olarak, yerel düzeyden ulusal düzeye doğru giden bir yönetim hiyerarşisi olduğunu söylemek mümkündür. Yönetim biçimleri olarak ise birkaç farklı yapı ile karşılaştığımızı görebiliyoruz. Hemen hemen incelenen bu ülkelerin tamamında ortak olarak bazı özellikler göze çarpmaktadır. Öncelikli olarak, bu ülkelerin tamamında yönetim sistemleri, Afet ve Acil Durum Yönetimi konusunun bir bilim dalı olduğu ve disiplinlerarası bir alanda faaliyet gösterdiği gerçeği üzerine inşa edilmiştir. Tüm tehlikeler ve tüm evreler yaklaşımı içselleştirilerek bu yaklaşım üzerine yönetim anlayışı oluşturulmuştur. Ulusal boyutta konunun yönetilmesi, bütünleşik yönetim 
anlayışını benimsemiş tek bir organizasyon sorumluluğunda gerçekleşmektedir. $\mathrm{Bu}$ organizasyon hiyerarşik olarak diğer kurumları koordine edebilecek bir hiyerarşik seviyede bulunmaktadır. Ayrıca, tüm paydaşların etkin katılımını teşvik eden ve her birinin konuyu sahiplenmesini sağlayacak bir yönetim yaklaşımı görülmektedir. Tüm faaliyetlerin alt fonksiyonları ile birlikte etkin ve verimli olarak yürütülmesi için detaylı bir planlama süreci ve ulusal düzeyde planlar mevcuttur. Endüstriyel afetler, enkaz yönetimi, atık yönetimi ve erken uyarı gibi konunun alt başlıklarında da sistematik çalışmalar yapıldığı ve yeni yasal düzenlemeler oluşturulduğu görülmektedir. Tüm bu çalışmalar kamu yönetiminin ilgili birimleri ile entegre olarak planlanıp yürütülmektedir. Tablo 1'de ülkeler; Sorumlu kamu otoriteleri, bilgi akışı ve yardımcı diğer kurumlar olmak üzere üç kritere göre değerlendirilmiştir.

Tablo 1. Ülkelerin Değerlendirilmesi Tablosu

\begin{tabular}{|c|c|c|c|c|c|}
\hline & Türkiye & ABD & Japonya & Fransa & Rusya \\
\hline $\begin{array}{l}\text { Afet ve Acil Durum } \\
\text { Yönetiminden } \\
\text { Sorumlu Kamu } \\
\text { Otoriteleri }\end{array}$ & $\begin{array}{l}\text {-İçişleri Bakanlığı } \\
\text {-AFAD }\end{array}$ & $\begin{array}{l}\text {-Federal Hükümet } \\
\text {-FEMA ( Acil } \\
\text { durum Yönetim } \\
\text { Ajansı) }\end{array}$ & $\begin{array}{l}\text {-Ulusal Ülke } \\
\text { Ajansı }\end{array}$ & $\begin{array}{l}\text {-İçişleri Bakanlığı } \\
\text {-DSC }\end{array}$ & $\begin{array}{l}\text { - Sivil Savunma, } \\
\text { Acil Durumlar ve } \\
\text { Doğal Afetler } \\
\text { Bakanlığı } \\
\text {-EMERCOM } \\
\text { (Ulusal Afet } \\
\text { Yönetim Merkezi) }\end{array}$ \\
\hline Bilgi Akışı & $\begin{array}{l}\text {-Cumhurbaşkanlığı } \\
\text { Makamı } \\
\text {-İçişleri Bakanlığı } \\
\text {-AFAD } \\
\text {-İ Valisi }\end{array}$ & $\begin{array}{l}\text {-ABD Başkanı } \\
\text {-Ülke Güvenliği } \\
\text {-FEMA } \\
\text {-Eyalet Yönetimi } \\
\text {-Yerel Yönetim }\end{array}$ & $\begin{array}{l}\text {-Başbakan } \\
\text {-Ulusal Ülke } \\
\text { Ajansı } \\
\text {-Afet Önleme } \\
\text { Bürosu (Vali) } \\
\text {-Belediye }\end{array}$ & $\begin{array}{l}\text {-İçişleri Bakanlığı } \\
\text { - Ulusal ADYM } \\
\text {-Bölgesel ADYM } \\
\text {-İl ADYM }\end{array}$ & $\begin{array}{l}\text {-Başbakan } \\
\text {-EMERCOM } \\
\text {-CMC (kriz } \\
\text { Yönetim Merkezi) }\end{array}$ \\
\hline $\begin{array}{c}\text { Yardımına } \\
\text { Başvurulan Diğer } \\
\text { Kuruluşlar }\end{array}$ & $\begin{array}{l}\text {-Diğer Bakanlıklar } \\
\text {-TSK } \\
\text {-Kızılay } \\
\text {-Akredite STK'lar }\end{array}$ & $\begin{array}{l}\text {-Özel Sektör } \\
\text {-ABD ordusu } \\
\text {-Ulusal Muhafızlar }\end{array}$ & $\begin{array}{l}\text {-JICA } \\
\text {-Milli Ülke Ajansı } \\
\text {-JDR }\end{array}$ & $\begin{array}{l}\text {-Diğer Bakanlıklar } \\
\text {-AB Ülkelerindeki } \\
\text { muhataplar }\end{array}$ & $\begin{array}{l}\text {-UEPRSS } \\
\text {-TSENTROSPAS } \\
\text {-SRS } \\
\text {-SFS }\end{array}$ \\
\hline
\end{tabular}

\section{Sonuç, Değerlendirme Yorum ve Öneriler}

5.

Dünyada ve ülkemizde, Afet ve Acil Durum Yönetimi alanında yaşanan gelişmeler doğrultusunda, konuyla ilgili olarak ülkemiz için yönetim stratejilerine yönelik bir takım öneriler yapmak mümkündür. Bunların bir bölümü bilimsel ve teknik öneriler, bir kısmı da uygulamaya yönelik, operasyonların iyileştirilmesine yönelik öneriler olarak sınıflanabilir. Bilimsel ve teknik önerilerden en önde geleni olarak; Türkiye'deki tarihsel sürecin yeni bir yaklaşımla yeniden tarihlenmesidir. Şöyle ki; ülkemizde afet yönetimi tarihi literatür incelendiğinde dört tarihsel döneme ayrılmış olsa da stratejik yönetim penceresinden baktığımızda asında üç bölümde incelenebileceği açıkça görülmektedir. 1999 yılı öncesi dönemde; meydan gelen olay sonucu yapılan düzeltme çalışmaları, olaya yönelik oluşturulan organizasyonlar ve buna yönelik çıkarılan kanun, yönetmelik vs. şeklinde bir yaklaşım görmekteyiz.

Bu dönemi, "Palyatif Çözümler Dönemi" olarak adlandırabiliriz. Çünkü afetlere bakış açısı, tekil afete odaklı ve sadece oluşmuş tekil afetin etkilerini en aza indirmeyi amaçlayan operatif ve yasal düzenlemeleri ihtiva etmektedir. 1999 yılında yaşadığımız Büyük Marmara Depremi sonrasında ise 2009 yılında AFAD organizasyonunun oluşması dönemine kadar olan süreyi ikinci bölüm olarak değerlendirmek mümkündür. Bu dönem "Sorunlarla Yüzleşme Ve Sistem Arayışı Dönemi“" olarak ifade edilebilir. Bu dönemde yalnızca müdahale odaklı yaklaşımın yetersiz kaldığı anlaşılmış bulunmaktadır. Dünyadaki örnekler incelenmeye 
başlanmış, konuyla ilgili yeni yönetim modelleri üzerinde çalışılmaya başlanılmıştır. Farklı kamu yönetimi organizasyonları hayata geçirilmiştir.

Son olarak ta 2009 yılından sonra Afet ve Acil Durum Yönetimi Başkanlığı'nın kurulması ile birlikte "Stratejik Bakış Dönemi" başlamıştır. Afet yönetiminde görülen koordinasyon ve yönetim problemleri karşısında önemli bir karar alınarak Yönetimin tek otoritede toplanması konusunda cesaretli bir adım atılmıştır. Afet ve acil durum yönetiminin aslında stratejik yönetim konusu olduğu ortaya konmuştur. Uygulamaya yönelik öneriler kapsamında ise; son yıllarda, özellikle endüstrideki gelişmeler doğrultusunda birçok farklı kavram ve yasal düzenleme konuya dâhil olmuştur. İş Sürekliliği, ISG, Atık Yönetimi, Büyük Endüstriyel Kazaların Önlenmesi Regülasyonu (SEVESO), Yüksek Güvenilirlikli Organizasyonlar (High Reliability Organizations-HRO) gibi bir takım yeni başlıklar, düzenlemeler ve uygulamalar hayatımıza girmiştir.

Yukarıda bahsedildiği üzere, Türkiye'de ki tarihsel sürecin yeniden tarihlenmesiyla ilgili olarak, literatürde bu yeni yaklaşımı aşağıda Şekil 8'deki gibi ifade edebiliriz.

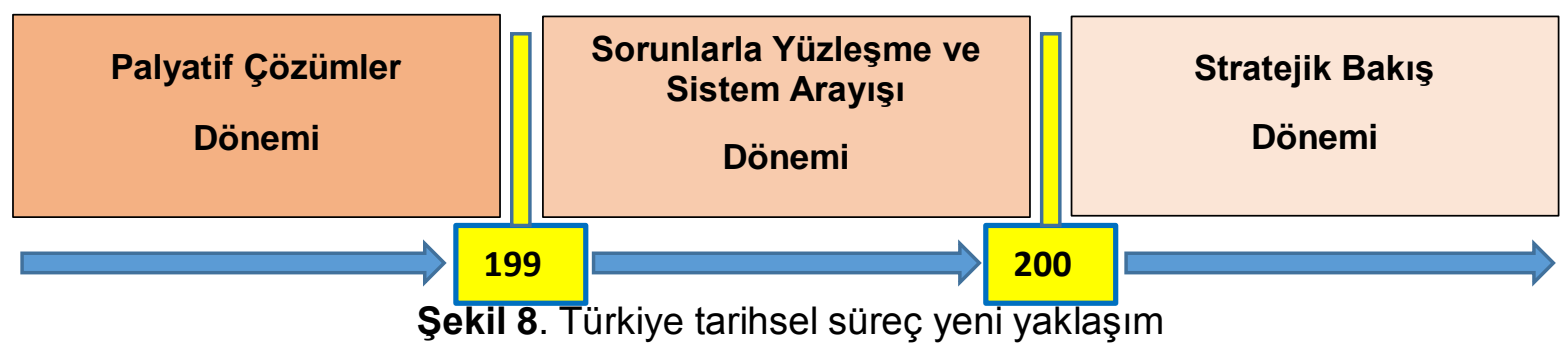

Bu gelişmeler ışığında, yönetim anlayışımızı ve organizasyon yapılarımızı güncellememiz gerekmektedir. Özellikle ISG faaliyetleri, SEVESO regülasyonu ve atık yönetimi konularındaki gelişmelerin, ara yüzler oluşturularak AFAD yönetim yapısına entegre edilmelidir. Söz konusu yeniliklerin ülkemizin yönetim yapısına uygunluğu ve kurumlar arası koordinasyon boyutu da gözden geçirilerek tekrar ele alınması gerekmektedir. Bu gelişmeler neticesinde, AFAD Organizasyon yapısının da güncellenmesi önem arz etmektedir. Bu hususla ilgili öneriyi aşağıdaki Şekil 9'da görmek mümkündür. Ayrıca, yeni geçiş yaptığımız "Başkanlık Sistemi" yönetim modelinin de Parlamenter Sistem anlayışıyla devam etmekte olan yapılara "uyumlaştırılması" gerekmektedir. Bu noktada Afet ve Acil Durum Yönetimi konusunda da koordinasyonun daha etkin olması açısından önemli bir fırsat oluşmaktadır. Müdahale aşamasında daha hızlı karar verme, aynı zamanda etkin koordinasyon en önemli kazanım olacaktır. Aynı şekilde iyileştirme aşamasında da, zararların azaltılması yeniden yapılandırmada önceliklerin belirlenmesi ve uygulamaya geçilmesi noktasında avantaj sağlayacaktır.

Bu çerçevede afet risk yönetimi yaklaşımının sadece ulusal bir anlayış olamayacağı, aksine uluslararası bir anlayış içersinde değerlendirilmesi gerektiği çok açıktır. Bu nedenle "küresel düşünüp yerel hareket etme" yaklaşımı ile afet risk azaltımı yaklaşımları örtüşmektedir (Özmen ve Özden, 2013).

$\mathrm{Bu}$ yeni gelişmelerle birlikte, yönetim sistemini destekleyecek, ve geliştirecek yeni bir "Türkiye Afet ve Acil Durum Yönetim Enstitüsü" nün kurulması ile ülkemizin topyekün afete dayanıklı / mukavim bir toplum olması hususunda önemli katkılarda bulunabileceği hususu da göz önünde bulundurulmalıdır. Bu Enstitü, öncelikli olarak profesyonel ve gönüllü afet çalışanlarının yetkinliklerini sağlamaya yönelik eğitim ve sertifikasyon hizmeti verebilir. Bunun yanı sıra global ve lokal akademik ilerlemeleri takip ederek, güncel gelişmeleri sahaya yansıtmak üzere gerekli faaliyetleri yürütmelidir. Aynı zamanda çevre ülkelere de (Hazar 
bölgesi ülkeleri, Körfez ülkeleri, Kuzey Afrika ülkeleri) eğitim ihracatı yapabileceğimiz bir enstitünün oluşturulması ülkemize bu konuda katma değer kazandıracak bir husustur. Ayrıca, bu yapı vasıtasıyla üniversite, endüstri ve STK'lar gibi diğer paydaşların da sisteme daha etkin biçimde dâhil edilerek, bilgi birikimi (Know-How) üretimi yapılan bir mükemmeliyet merkezi haline gelmesi sağlanabilir.

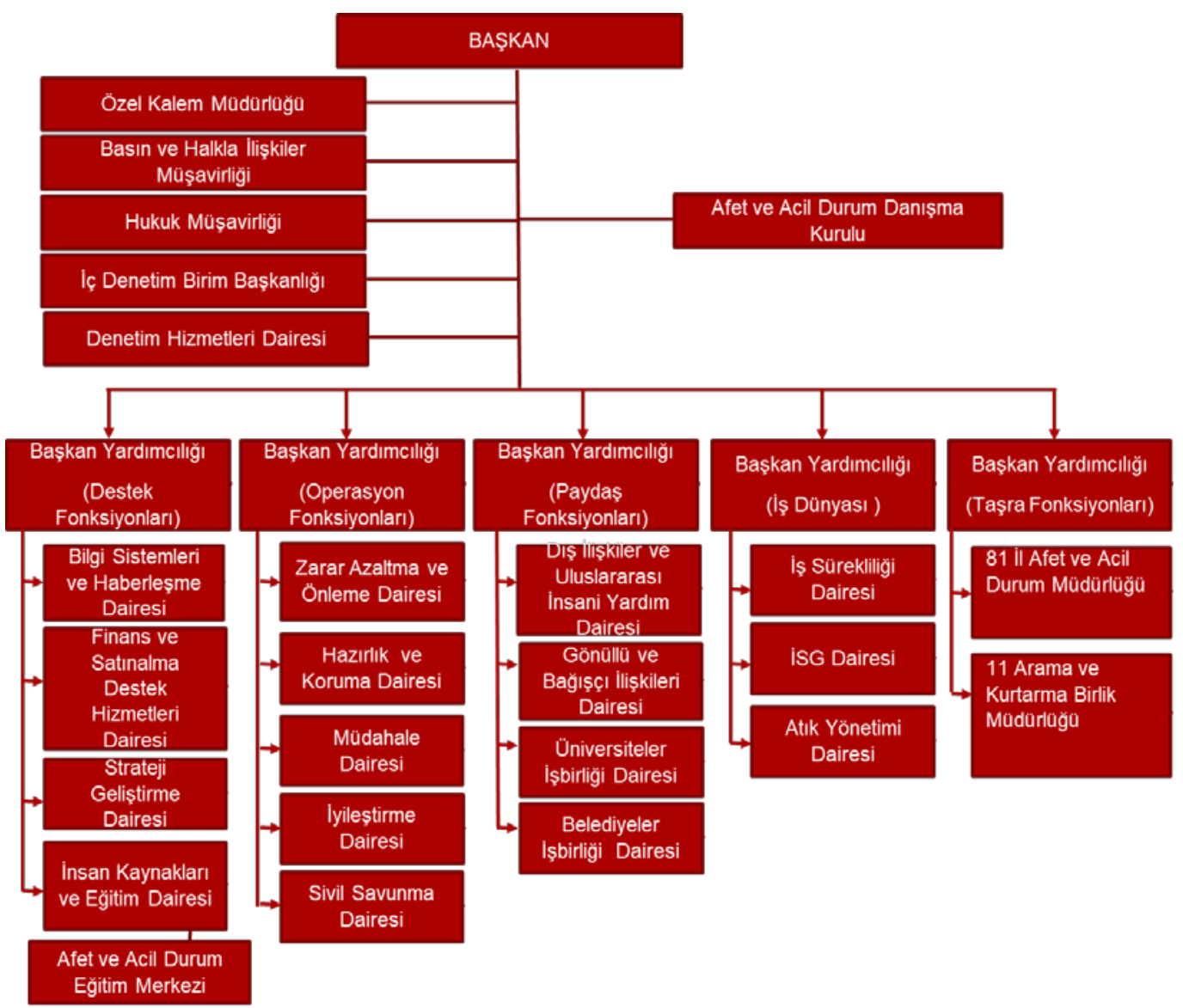

Şekil 9. Türkiye AFAD Organizasyonu için önerilen Organizasyon Şeması

\section{KAYNAKLAR}

5393 Sayılı Belediye Kanunu, 13/7/2005 tarih ve 25874 sayılı Resmî Gazete.

5902 Sayılı Afet ve Acil Durum Yönetimi Başkanlığının Teşkilat ve Görevleri Hakkında Kanun, 05.03.2018, http://www.mevzuat.gov.tr/MevzuatMetin/ 1.5.5902.pdf 14.Ocak.2020 tarihinde alındı.

AFAD (2010). Başbakanlık Afet ve Acil Durum Yönetimi Başkanlığı, Başbakanlık Afet ve Acil Durum Yönetimi Başkanlığı, 48. sayfa.

AFAD (2015a). Hyogo Raporu (2013-2015), Ankara.

AFAD (2015b). Sendai Afet Risklerinin Azaltılması Raporu.

EMERCOM (2012). EMERCOM of Russia Country Report. https://www.adrc.asia: https://www.adrc.asia/countryreport/RUS/RUSeng98/index.html adresinden 19.Mart.2020 tarihinde alındı 
Emergency Management Institute (2014). Comparative Emergency Management Book. Washington DC: FEMA, USA.

European Commision (2019). Vademecum of Civil Protection - European Commision. http://ec.europa.eu: http://ec.europa.eu/echo/files/civil_protection/vademecum/fr/2-fr.html adresinden 10.Mart.2020 tarihinde alındı.

Federal Disaster Management Agency (2014). "State Organization and Role in Emergency Management." Last modified May 28, 2014b. http://www.fema.gov/about-agency. adresinden 21.Mart.2020 tarihinde alındı

Federal Office of Civil Protection and Disaster Assitance (2018). Federal Office of Civil Protection and Disaster Assitance.

https://www.bbk.bund.de/EN/FederalOffice/Chronicle/chronicle_node.html adresinden 21.Şubat.2020 tarihinde alındı.

FEMA (2018). Strategic Plan 2018-2022. U.S.FEMA, DC.

FEMA. (2014). Federal Disaster Management Agency. "State Organization and Role in Emergency Management." Last modified May 28, 2014b. FEMA http://www.fema.gov/aboutagency. adresinden 11.Mart.2020 tarihinde alındı

Government of Japan (2007). Disaster Management System in Japan. Tokyo: Government of Japan. http://www.fema.gov/strategic-plan

Index for Risk Management. (2019). INFORM Report 2019 shared evidence for managing crises and disasters. INFORM.

Kadıoğlu, M. (2008). —Modern, Bütünleşik Afet Yönetimin Temel İlkeleri,M. Kadıŏlu ve E. Özdamar (Editörler), —Afet Zararlarını Azaltmanın Temel İlkeleri, JICA Türkiye Ofisi Yayınları No: 1, Ankara, s. 1-34.

Kapucu, N. (2008). Collaborative emergency management: better community organising, better public preparedness and response. Disasters, s. 249.

Kapucu, N. (2010). Disaster and Crisis Management in Turkey: A Need for a Unified Crisis Management System. Disaster Prevention and Management. s. 160.

Leblebici, Ö. (2014). Afetlerde Kamu Yönetimnin Rolü ve Toplum Temellik Afet Yönetimine Doğru. Hitit Üniversitesi Sosyal Bilimler Enst. Dergisi, 457-477.

Liyanaarachchige, C. (2016). Report: A Study on the Disaster Management Framework of Japan. Tokyo: Asian Disaster Reduction Center.s.21.

Macit İ. (2019). Bütünleşik Afet Yönetiminde Sendai Çerçeve Eylem Planının Beklenen Etkisi http://static.dergipark.org.tr/article-download/1bbb/cbaa/d81e/5c37247ccf059.pdf

McEntire, D.A., Fuller, C., Johnston, C.W., Weber, R. A. (2002). Comparison of Disaster Paradigms: The Search for a Holistic Policy Guide, Public Administrative Review, 62 (3): 267-281.

Okay N. (2018). Afete Direncli Kentlerde Risk Azaltma. Search for a Holistic Policy 
Okay N. (2019). Afet Risk Yönetiminde Yaklaşımlar. Mimar ve Mühendis (109): 54-57.

Okay N., İnal E. (2019). Kırılganlıktan Kapasiteye. Resilience 3(1): 85-99.

Özerdem, A., Jacoby, T. (2006). Disaster Management and Civil Society: Earthquake Relief in Japan, Turkey And India, I. B. Tauris, London and New York: Distributed in the USA by Palgrave Macmillan, New York.

Özmen B., Özden, A. T. (2013). Türkiye'nin Afet Yönetim Sistemine İlişkin Eleştirisel Bir Değerlendirme. Journal of Faculty of Political Science, (49): 1-28.

Rubin, C. (2007). Emergency Management: The American Experience 1900-2005. Fairfax: PERI.S.1175.

Seneviratne, D. B. (2011). Disaster knowledge factors in managing disasters. International Journal of Strategic Property Management, s. 380.

Şener, S.M., Kadıoğlu M., İskender H., Tezer A., Helvacıoğlu İ. (2003). Ulusal Acil Durum Yönetimi Modeli,. ITÜ Yayınları

TC İçişleri Bakanlığı. (2019). İçişleri Bakanlığı. https://www.icisleri.gov.tr/teskilat-semasi-2019 adresinden 23.Mart.2020 tarihinde alındı.

Tercan, B. (2018). Türkiye'de afet politikaları ve kentsel dönüşüm. Abant Kültürel Araştırmalar Dergisi - Abant Journal of Cultural Studies, 3(5): 63-74. https://dergipark.org.tr/en/pub/akader/issue/36855/413249 1.Mart.2020 tarihinde alındı.

UNDRR (2019). UN Office for Disaster Risk Reduction ( UNDRR). https://www.unisdr.org: https://www.unisdr.org/partners/countries/fra adresinden 10.Mart.2020 tarihinde alındı

UNISDR (2015). Sendai Framework for Disaster Risk Reduction 2015-2030. United Nations Office for Disaster Risk Reduction. United Nations, Geneva, 37 sayfa.

UNISDR (2019). Making Cities Resilient Report 2019. United Nations Office for Disaster Risk Reduction,https://www.unisdr.org/campaign/resilientcities/assets/toolkit/documents/UNDRR Making\%20Cities\%20Resilient\%20Report\%202019_Executive\%20Summary_April2019.pdf. 12.Şubat.2020 tarihinde alındı.

United Nations (2015). Transforming Our World: The 2030 Agenda for Sustainable Development: United Nations, Geneva, 35 s.

Varol, N., Kırıkkaya, E. B. (2017). Afetler Karşısında Toplum Dirençliliği. Resilience. 1(1): 1-9 Yaman, F. (2020). Ulusal afet ve acil durum yönetimi için yeni bir yönetim yaklaşımı modeli önerisi. Doktora Tezi. İstanbul: İstanblu Arel Üniversitesi, Sosyal Bilimler Enstitüsü.

Yaman, F., Ayrancı, E., \& Helvacıoğlu, İ. H. (2019). Türkiye Afet ve Acil Durum Yönetimi Sistemi için Bir Değerlendirme. IDRC 2019 Makale özeti sunumu. Eskişehir: IDRC 2019. s.205. 